\title{
Development of reservoir operation rules using seasonal climate forecasts
}

\section{Definição de regra de operação de reservatórios com uso de previsões climáticas sazonais}

\author{
Andressa Adna Cavalcante Morais $^{1}$ (D) \& Adelena Gonçalves Maia ${ }^{1}$ (D) \\ ${ }^{1}$ Universidade Federal do Rio Grande do Norte, Natal, RN, Brasil \\ E-mails: andressa_adna@hotmail.com (AACM), adelenam@gmail.com (AGM)
}

Received: January 28, 2021 - Revised: June 02, 2021 - Accepted: June 04, 2021

\begin{abstract}
This study verified the suitability of using precipitation forecasts in defining operation rules for the Cruzeta reservoir in Rio Grande do Norte, Brazil. The operation rules were developed through reservoir operation simulation-optimization, using a genetic algorithm. The performance indicators were analyzed in five operation scenarios: standard operating policy (SOP), current reservoir rationing rule $(\mathrm{C})$, rationing without forecast $(\mathrm{R})$, rationing with forecast $(\mathrm{RF})$, and rationing with perfect forecast (RPF). The SOP scenario better met the total demand but made the system very susceptible to supply collapse. The results of the RF and RPF scenarios showed better compliance with the priority demands and the total demand during the dry periods. Changing from RF to RPF scenario, there is a small improvement in the evaluation indexes. The use of rules integrating the seasonal weather forecast is thus recommended.
\end{abstract}

Keywords: Optimization, Operation rules, Water scarcity.

\section{RESUMO}

Esta pesquisa verificou a adequabilidade do uso das previsões de precipitação na definição de uma regra de operação do reservatório Cruzeta $(\mathrm{RN})$. As regras de operação foram definidas a partir da simulação e otimização, via algoritmo genético, da operação do reservatório. Os indicadores de desempenho foram analisados segundo cinco cenários de operação: política de operação padrão (SOP), regra atual de racionamento $(\mathrm{C})$, racionamento sem previsões $(\mathrm{R})$, racionamento com previsão $(\mathrm{RF})$ e racionamento com previsão perfeita (RPF). O cenário SOP foi o que melhor atendeu a demanda total, mas tornou o sistema muito susceptível ao colapso no abastecimento. Os resultados do RF e RPF mostraram uma melhor conformidade no atendimento das demandas prioritárias e da demanda total nos períodos secos. Mudando o cenário de RF para RPF houve uma pequena melhoria nos índices de avaliação. O uso de regras integrando a previsão do tempo sazonal é, portanto, recomendado.

Palavras-chave: Otimização, Regra de operação, Escassez hídrica. 


\section{INTRODUCTION}

As the world population grows, more water will be required to satisfy the basic needs of the population. The water supply, however, may come at a high financial and ecological price (Ragab \& Prudhomme, 2002). The problems in water resource management remain challenging today and are projected to remain challenging in the future, if not more challenging due to certain developments in several related sectors, such as irrigation and industry. The effects of climate change may also make these problems more complex (Allawi et al., 2019). Trends such as population growth, pollution, increasing demand for food and water, and market fluctuations can compound the impact of climate variability and climate change (Índia, 2016).

The periodic occurrence of droughts in the Northeast Region of Brazil has been recorded since the 16th century and discussed since the 19th century. The droughts are intense and have a considerable impact on the people and their means of livelihood (Gondim et al., 2017). For a region where all rivers remain dry for more than 6 months each year, politicians first planned to accumulate water in reservoirs to guarantee year-round water access. Reservoir construction was thus the first approach used to solve Northeast Brazil drought issues. Public policies were characterized by this approach from the start of drought public policy formulation in 1877 until the early 1950s (Campos, 2015).

Droughts result from the interaction among several spheres, such as the atmosphere, hydrosphere, biosphere, and anthroposphere. They have extensive effects, such as on water resources, agriculture, animal husbandry, environmental ecosystems, and public health (Guo et al., 2018). As complex natural hazards, droughts are best characterized by multiple climatological and hydrological parameters (Mishra \& Singh, 2010).

The especially severe drought in the Northeast Region of Brazil starting in about the year 2012 and lasting until at least 2018 appeared to have provided a window of opportunity to intensify the debate on the matter because the different parties concerned (water users, public administration, civil society, and traditional communities) went through a substantial learning process due to the unavailability or unreliability of water supply during such period (Koch et al., 2018). The drought caused the agricultural, cattle ranching, and water supply sectors to incur much loss. Some local economies were also affected, prompting the federal government to authorize the release of funds for the affected districts to mitigate the negative impact of the drought on the people (Marengo et al., 2018).

The Brazilian semi-arid region encompasses a $981,000 \mathrm{~km}^{2}$ area with 1,135 municipalities and almost 24 million inhabitants, accounting for almost $12 \%$ of the country's population. It should be noted that around 10 million of the region's residents are inhabiting the rural area (Agência Nacional de Águas, 2020). Although drought is a recurrent phenomenon in the Northeast Region of Brazil, the risk that it poses and the region's vulnerability to it are perceived as still high, particularly in the semi-arid rural areas. There is thus a need for action on the part of the scientific community and decision makers to address the drought-related issues, focusing on reducing the region's vulnerability to it and building resilience (Marengo et al., 2018).
Reservoirs allow temporary storage of volumes of water; in other words, water can be accumulated in reservoirs in times of abundance and can be released in times of drought or when there is a high water demand (Koch et al., 2018). As dam and reservoir systems are important hydraulic infrastructures in the field of water resources management, the rules for the ideal operation of reservoir systems must be determined (Allawi et al., 2019).

Reservoir operation rules concern the regulation of the release of water to meet several purposes (Bolouri-Yazdeli et al., 2014). The standard operating policy (SOP) is the simplest and most often-used reservoir policy: that if possible, only the amount of water required in each period be released so that water can be preserved for future requirements (Rittima, 2009). However, SOP is not the ideal policy for reservoir operation because it causes large, single-period shortage or vulnerability (Chiamsathit et al., 2014).

The reservoir rule curves and the hedging rules provide operating guidelines that can be followed to minimize the impact of a drought when reservoirs are drawing down because of insufficient inflow (Tu et al., 2003). Hedging policies can offer effective and low-cost adaption and mitigation strategies for climate change (Adeloye \& Dau, 2019).For hedging to be useful, water saving must be done during periods of normal reservoir operation, not when the water is already in short supply (Chiamsathit et al., 2014).

Semi-arid regions are characterized by the high temporal and spatial variability of rainfall, resulting in high uncertainty in rainfall estimations (Trambauer et al., 2013). According to Marengo et al. (2018), in climatic terms, semi-arid regions are vulnerable to the observed extremes of interannual climate variability, mainly droughts, and the climate change scenarios indicate that the region will experience rainfall deficit and increased aridity in the second half of the $21^{\text {st }}$ century. The high level of uncertainty regarding hydrological inflows has a dramatic impact on the decisions made regarding the assigning of water resources to demand centers, making long-term management planning difficult (Pallottino et al., 2005).

The seasonal rainfall forecasting should be incorporated into the use of the rule curve, allowing, with the announcement of a possible water crisis, withdrawals are limited to the grantable flow (Nunes et al., 2016). Knowledge of forecast uncertainty stemming from climatic and hydrological models allows for improved forecasting and probabilistic evaluation within water resources decision making. Properly accounting for this uncertainty, however, remains a formidable challenge (Block et al., 2009). In addition, forecasting models do not necessarily improve reservoir management; for improvements to occur, the management process (or model) must also use forecast information effectively (Yao \& Georgakakos, 2001).

Rainfall is one of the major hydrologic variables affecting water supply; thus, estimating future rainfall is very important for planning and management of water recourses and agriculture (Choubin et al. 2014). Fan et al. (2016) and Peng et al. (2019) used precipitation forecasts to generate forecasts of the inflows of reservoirs that generate electricity in Brazil and China, respectively, using the rainfall-runoff model. Bravo et al. (2008a, 2008b) and Ficchí et al. (2016) simulated the management of a reservoir system for energy generation and flood control, basing its operation on rule curves, deterministic forecasts, and overall forecasts. The simulation 
results were compared with the results of the operation based on perfect forecasts, which present the performance in the ideal case in which the seasonal climate forecasts are not affected by any type of uncertainty. The real forecast operation provided results nearly as good as those provided by the perfect forecast operation. Another case study of reservoir operation methods by Nohara \& Hori (2018) showed that considering ensemble hydrological predictions in a real-time optimization of the water release strategy, conducted using dynamic programming approaches, generally mitigate drought damage more than do the historical flow regimes that do not take forecasts into account.

In Brazil, there are seasonal climate forecasts made available by some study centers, such as the National Institute of Meteorology - INMET, the Center for Weather Forecast and Climate Studies - CPTEC, INPE and the Drought Monitor of the National Water Agency - ANA. Climate forecasts from a statistical forecast model (Lúcio et al., 2010) are available and support INMET in the generation of a seasonal climate forecast for the following quarter are available. The INMET statistical model presents good prediction performance even in the Midwest and Southeast Region of Brazil, where the currently available numerical models have low levels of dexterity (Instituto Nacional de Meteorologia, 2019b).

In this context, this study aimed to quantify the improvement in meeting demands, with the development of reservoir operation rules based on precipitation forecasts. The following operation rules were compared: standard operating policy (SOP), current reservoir rationing rule $(\mathrm{C})$, and optimized rationing rules integrating precipitation forecasts (rationing with forecast, RF), not integrating precipitation forecasts (rationing without forecast, R), and integrating perfect precipitation forecasts (rationing with perfect forecast, RPF).

\section{MATERIALS AND METHODS}

\section{Study area}

The study area (Figure 1) is the Cruzeta reservoir located in the semi-arid region of Rio Grande do Norte (Brazil), in the Piancó-Piranhas Açu river basin, Seridó sub-basin.

The reservoir has a 616.11 ha hydraulic basin and a $23.55 \mathrm{hm}^{3}$ storage volume, with a $1.18 \mathrm{hm}^{3}$ dead volume, according to the bathymetric survey carried out in 2010. This reservoir can meet a $0.25 \mathrm{~m}^{3} / \mathrm{s}$ flow with a $90 \%$ guarantee (Agência Nacional de Águas, 2016a) and meets the demands for irrigation, human supply, animal feed (livestock), and industrial supply, as shown in Table 1.

Figure 2 shows the monthly averages of precipitation (data provided by the Agricultural Research Corporation of Rio Grande do Norte [EMPARN]), evaporation, and affluent flow (Agência Nacional de Águas, 2016b) in the reservoir.

The rainfall in the basin is concentrated in February to May and is characterized by high interannual variability. Seridó sub-basin has lower average values. In the Cruzeta reservoir, it rains an average of $513 \mathrm{~mm} /$ year, with maximum rains in the months of March and April. There are also high evaporation rates, which cause significant losses of water reserves, thus contributing to the water deficit in the basin. The average Piché evaporation of the basin is $2,338 \mathrm{~mm} /$ year, and the highest rates are generally observed from August to January (Agência Nacional de Águas, 2016b). As for the average monthly affluent flow of the Cruzeta reservoir, it can be seen that the largest influx of water via precipitation occurs from March to June, with the maximum values in April and May.

The storage volume data for the Cruzeta reservoir (Rio Grande do Norte, 2020) are shown in Figure 3.

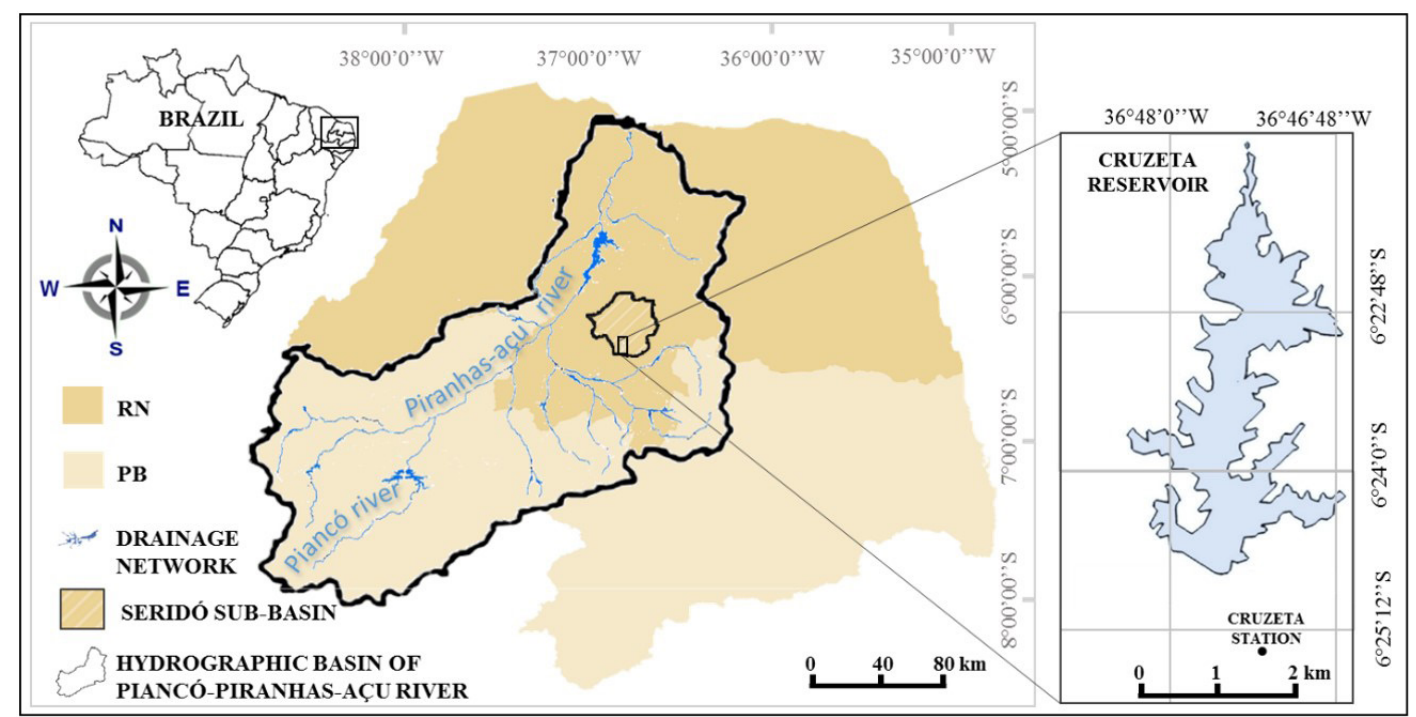

Figure 1. Cruzeta reservoir location.

Table 1. Demands from the Cruzeta reservoir (Agência Nacional de Águas, 2016a).

\begin{tabular}{cccccr}
\hline \multicolumn{2}{c}{ Priority demands $\left(\mathrm{m}^{3} / \mathbf{s}\right)$} & & \multicolumn{2}{c}{ Non-priority demands $\left(\mathrm{m}^{3} / \mathbf{s}\right)$} & \multirow{2}{*}{ Total demand $\left(\mathrm{m}^{3} / \mathbf{s}\right)$} \\
\cline { 1 - 2 } & Livestock & Irrigation & Industrial & \\
\hline 0.028 & 0.026 & 0.874 & 0.010 & 0.938 \\
\hline
\end{tabular}




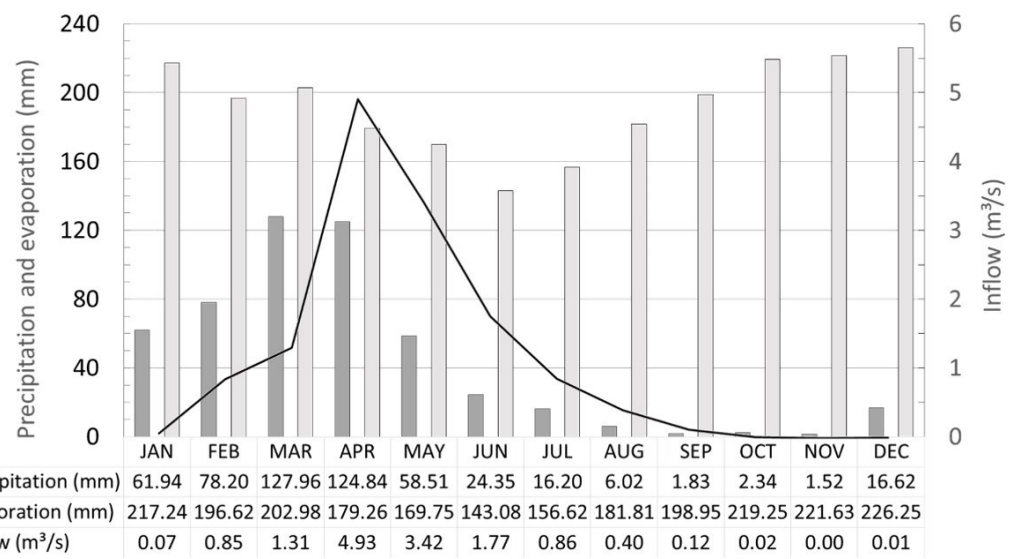

Figure 2. Monthly averages of precipitation, evaporation, and inflow in the reservoir.

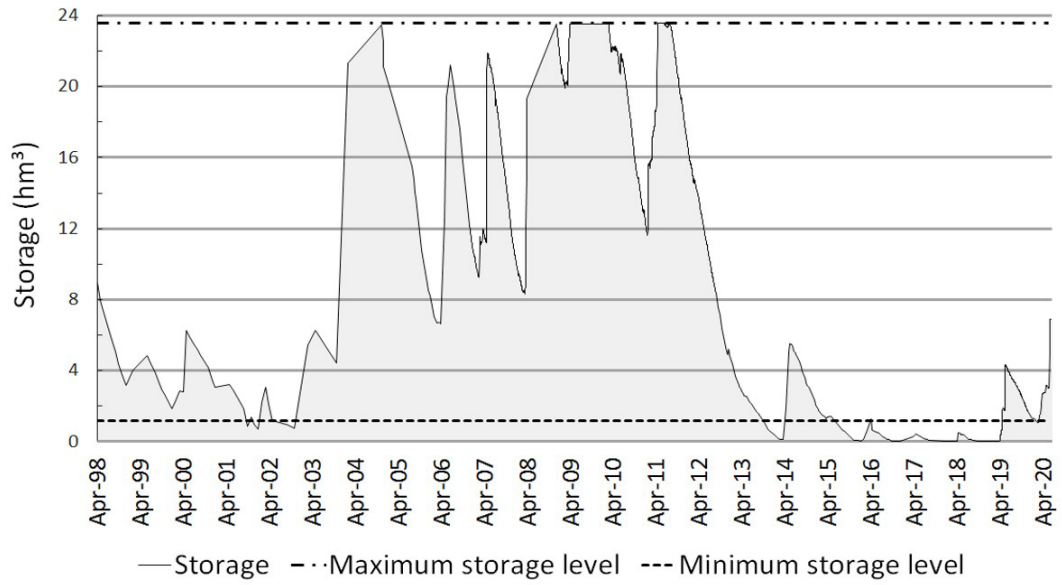

Figure 3. Cruzeta reservoir storage.

It was noted that from 2013 to 2018, the Cruzeta reservoir was vulnerable to suffer another prolonged drought period. In November 2015, the local reservoir, which was supplying water to the over 8,000 inhabitants of the city of Cruzeta, dried up. Companhia de Águas e Esgotos do Rio Grande do Norte, company responsible for water supply, had been serving on a rotating basis, but the low level of the source made water supply unfeasible (G1 RN, 2015). Water was thus distributed through water trucks. Even when the water level was below the dead volume (from 2016 to 2018), the supply reservoir was used (Associação Brasileira das Empresas Estaduais de Saneamento, 2017; Grupo Agora RN, 2016; G1 RN, 2018). The system reestablished its minimum operation level in April 2019 (Grupo Agora RN, 2019). However, it is important to note that drought was just another aggravating factor in shortages, as the reservoir is already overexploited since its demand corresponds to about $23 \%$ of flow with a $90 \%$ guarantee (Table 1 ).

Most of the reservoirs located in the semi-arid region of $\mathrm{RN}$ have required demands higher than the water availability, which corroborates the frequent scenario of water scarcity experienced in the region. Although most reservoirs do not have water availability to meet the total demand $90 \%$ of the time, they have sufficient flows to guarantee that priority uses are met (Castro et al., 2018). The obtained information shows the difficulty of meeting the demands imposed and the need to overcome the large water deficit during the aforementioned period through the intelligent use of resources. The prolonged drought in the semi-arid region since 2012 has led to another series of initiatives by ANA to address the situation. Among the planned initiatives, based on the identified need to deepen the knowledge about the water supply and demands and the operating conditions of the reservoirs, was the gathering of information about the current water balance in the region and about the improvement needed in the operation of the reservoirs in the region (Agência Nacional de Águas, 2017b).

There are available operation rules for reservoirs based on the risk aversion curves, aiming at meeting the greatest possible number of demands. Such rules indicate the need to operate the reservoirs/reservoir systems with restrictions on meeting demands and with the provision of subsidies to the managing body for greater efficiency and rationality in planning and managing the water resources in the semi-arid region (Agência Nacional de Águas, 2017). Cruzeta reservoir rationing rule will be presented later.

\section{Reservoir behavior with different operation rules}

In this study, different operation scenarios of the Cruzeta reservoir were compared. In these scenarios, the following rules 
were considered: SOP; the current operation rule of the reservoir; the operation rule via optimization of demand fulfillment, considering the future scenarios of precipitation, with real and perfect seasonal climate forecasts. The latter being forecasts that can perfectly match the classification of the quarterly accumulated precipitation, verifying the maximum efficiency of the operation less affected by uncertainties.

For the development of operation rules, a simulation of the reservoir's water balance was performed, along with its optimization using a genetic algorithm to maximize the efficiency of meeting the water demands.

Simulation of water balance

A reservoir is a system with its own hydrodynamics, composed of inflows of natural flow and direct precipitation and of outlets through evaporation, spillage, and water intake. In this study, the behavior of the water accumulated in the reservoir was analyzed using the monthly water balance modeling of the reservoir, associated with the operation rules determined in the different scenarios.

The formulation of the water balance is expressed by Equation 1:

$S_{t f}=S_{t}+Q_{t}+\left(P_{t}-E_{t}\right) \cdot A_{m e d t}-D^{\prime}{ }_{t}-S p_{t}$

where $S_{t f}$ is the volume storedat the end of $\Delta \mathrm{t}$ interval $\left(\mathrm{m}^{3}\right), S_{t}$ is the volume storedat the beginning of $\Delta \mathrm{t}$ interval $\left(\mathrm{m}^{3}\right), Q_{t}$ is the natural inflow volume in the $\Delta \mathrm{t}$ range $\left(\mathrm{m}^{3}\right), P_{t}$ is the spatial average precipitation over the reservoir lake area in the $\Delta$ t interval ( $\mathrm{m} / \mathrm{month}$ ), $E_{t}$ is the spatial average evaporation over the reservoir lake area in the $\Delta \mathrm{t}$ interval (m/month), $A_{\text {medt }}$ is the average area of the reservoir in the $\Delta \mathrm{t}$ range $\left(\mathrm{m}^{2}\right), D_{t}^{\prime}$ is the volume of water supplied in the $\Delta \mathrm{t}$ range to a reference demand $\left(\mathrm{m}^{3}\right)$, and $S p_{t}$ volume of water flow downstream from the reservoir in the $\Delta t$ interval $\left(\mathrm{m}^{3}\right)$.

Physical and operational limitations determine the lower and upper limits for release, storage, and spilled volume, as shown in the following equations:

$$
0 \leq D_{t}^{\prime} \leq D_{t}
$$

$S_{\min } \leq S_{t} \leq S_{\max }$

$S p_{t} \begin{cases}=0 & \rightarrow \text { If } S_{t f}<S_{\max } \\ =S_{t f}-S_{\max } & \rightarrow \text { If } S_{t f}>S_{\max }\end{cases}$ where $S_{\min }$ is the dead volume $\left(\mathrm{m}^{3}\right)$ and $S_{\max }$ is the maximum volume $\left(\mathrm{m}^{3}\right)$.

To carry out the simulations, data on the reservoir's physical characteristics were used, such as level-area-volume curve and maximum and minimum storage capacities (Rio Grande do Norte, 2020). Water balance data were also used, such as the demands for water use (Agência Nacional de Águas, 2016a), the historical precipitation series provided by EMPARN, the affluent flow series, and the average monthly evaporation (Agência Nacional de Águas, 2016b). For the climate forecasting scenarios, the quarterly precipitation forecasts presented by INMET (Instituto Nacional de Meteorologia, 2020) in the Seasonal Climate Prognostics were used.

\section{Precipitation forecasts}

INMET produces monthly total rainfall forecasts for the whole of Brazil. Since February 2004, the seasonal climate forecasts have usually expressed the precipitation forecasts generated by the national multi-model system (CPTEC, INMET, and FUNCEME Foundation Cearense for Meteorology and Water Resources) due to the probability that the accumulated rain in the next three months in a given region will be "below the normal range," "within the normal range," or "above the normal range." In June 2011, the forecasts also started to have an equal probability rating for the three categories.

A normal range means the average tertile of the climatological distribution of accumulated rain in a given location in the quarter in question. The climatology of the normal range (a reference for climatic prognoses) of the Cruzeta Station (code 82693), is shown in Table 2. The reference period for the climatology is 1981-2010.

To express the prognosis information in physical terms ( $\mathrm{mm}$ of rain), it is necessary to know the lower and upper limits of the normal range (percentiles 33 and 67) for the quarter in question. If the forecast of accumulated precipitation for the quarter is below the lower limit, it is said to be below the normal range. If there are values from the lower limit to the upper limit, then this is the normal range for that quarter. If the forecast of accumulated precipitation for the quarter is above the upper limit, it is said to be above the normal range. Table 2 also shows the average accumulated quarterly precipitation, which is not a reference for the classification of periods but allows the observation that the Feb/Mar/Apr quarter is historically the rainiest (with $371.6 \mathrm{~mm}$ rainfall) while the Sep/ Oct/Nov quarter is the driest (with $13.5 \mathrm{~mm}$ rainfall).

Operation rules development

The decision variables in the scenarios development of the Cruzeta reservoir were obtained using a simulation-optimization

Table 2. Accumulated rainfall in the period (mm) - Cruzeta Station (Instituto Nacional de Meteorologia, 2019a).

\begin{tabular}{|c|c|c|c|c|c|c|c|c|c|c|c|c|}
\hline \multirow{3}{*}{ QUARTER } & JAN & FEB & MAR & APR & MAY & JUNE & JULY & AUG & SEP & OCT & NOV & DEC \\
\hline & FEB & MAR & APR & MAY & JUNE & JULY & AUG & SEP & OCT & NOV & DEC & JAN \\
\hline & MAR & APR & MAY & JUNE & JULY & AUG & SEP & OCT & NOV & DEC & JAN & FEB \\
\hline Lower limit & 233.2 & 281.7 & 239.8 & 145.4 & 67.3 & 33.3 & 10.8 & 2.8 & 2.4 & 8.9 & 60.4 & 123.9 \\
\hline Average & 310.8 & 371.6 & 340.0 & 233.9 & 114.6 & 59.2 & 29.1 & 16.1 & 13.5 & 34.7 & 106.8 & 195.0 \\
\hline Upper limit & 353.7 & 422.1 & 389.9 & 269.6 & 132.0 & 68.1 & 31.9 & 15.1 & 12.8 & 35.6 & 122.8 & 224.8 \\
\hline
\end{tabular}


model applying genetic algorithm (GA), which is a random search optimization algorithm inspired by biological evolution that provides a robust method for finding the ideal solution for complex problems (Michalewicz, 1992). This process used by Chang et al. (2010) obtain an optimal strategy for reservoir operations, to assist the decision-making process. GA proposes a dominant optimization method for the planning and management of reservoir operations (Anand et al., 2018). Such method has been widely applied in studies of reservoir operations to develop ideal rule curves and operational and rationing policies (Adeloye \& Dau, 2019). The fact that GA could be combined with a simulation model was seen as a real advantage, facilitating its implementation by decision makers (Wafae et al., 2016). To start the optimization of the GA, initial solutions (or chains) are randomly generated. Three fundamental operations are involved in manipulating the chains and moving to a new generation: selection, crossing, and mutation. The selection operation helps identify the best individuals to be included in the reproduction process for developing the next generation of chains through crossing and mutating. GA is usually repeated in several initial solutions generated at random, and the average of the best solutions or the best solution is taken as the final solution (Adeloye \& Dau, 2019).

According to Chang et al. (2010), a penalty function can be used to deal with the restrictions in the GA. The penalty cost is a function designed to penalize unviable solutions.

The optimization in this study was developed in the $\mathrm{R}$ language ( $\mathrm{R}$ Core Team, 2018) using the GA package developed by Scrucca (2013). The program was started by generating a population of possible decision variables. A population size of 200 individuals was assumed for each generation, with a mutation rate of 0.05 and a stopping criterion of 300 generations. These 200 potential responses for the decision variable were applied to the water balance simulation process to determine the value of the objective function to be optimized. The restrictions were converted into penalties and were added to the objective function.

\subsubsection{Proposed scenarios}

Two base scenarios and five application scenarios were developed to assess the efficiency of incorporating precipitation forecasts into the reservoir operation. Table 3 presents the variables derived from the base scenarios. Through these scenarios, we sought to determine the best management strategy for the operation of the Cruzeta reservoir on the basis of the hydrological conditions recorded in the period from 1964 to 2012, for use in the application scenarios. Scenarios $\mathrm{D}_{1}$ and $\mathrm{D}_{2}$ calculated the optimal values ofthe variables, and $\mathrm{SOP}_{1}$ was an auxiliary scenario simulated for a preliminary analysis of the differences in meeting the demands of the three scenarios presented.

The SOP 1 scenario simulated SOP, the simplest operation rule as it does not perform any rationing. According to SOP, the water demand must be met whenever there is enough water for such demand; that is, all the stored water must be released to meet the demands to the extent possible.

In scenario $\mathrm{D}_{1}$, critical levels of storage and water release coefficients were delimited by the rule curves, which consist of zones of restriction in meeting water demands (Figure 4). The lower rule curve (LRC) defines the alert level for conservation purposes. Maximum storage $\left(\mathrm{S}_{\max }\right)$ is the maximum accumulation capacity of the reservoir; the spillage begins after it is reached. Critical curves $\mathrm{CR}_{1}$ and $\mathrm{CR}_{2}$ define the storage values, which are triggers for rationing in the associated proportion. It was noted that the rationing is done in two stages and that the rationing factors in the supply demand, $\alpha_{1}$ and $\alpha_{2}$, meet the $0 \leq \alpha_{2} \leq \alpha_{1} \leq 1$ condition (Chiamsathit et al., 2014).

In scenario $\mathrm{D}_{1}$, four variables were optimized: the rationing trigger volumes (annual $\mathrm{CR}_{1}$ and annual $\mathrm{CR}_{2}$ ) and the demand release coefficients $\left(\alpha_{1}\right.$ and $\left.\alpha_{2}\right)$. The dead volume of the reservoir was defined as the volume of the LRC. This scenario was subject to restrictions $\mathrm{R} 1$ and $\mathrm{R} 2$ :

$$
R 1: \quad L R C \leq C R_{2} \leq C R_{1} \leq S_{\text {máx }}
$$

$R 2: \quad 0 \leq \alpha_{2} \leq \alpha_{1} \leq 1$

In the simulation-optimization of the reservoir operation performed by the AG, the objective function that could maximize the efficiency of meeting the priority demand $\left(Y_{p r i}\right)$ was sought, respecting the following penalties that ensures $\mathrm{R} 1$ and $\mathrm{R} 2$ conditions:

$$
\operatorname{Ypri}(D 1)=\frac{\sum_{t=1}^{T} D_{p r i}^{\prime}}{\sum_{t=1}^{T} D_{p r i}}-\text { Penalty1 }- \text { c. Penalty } 2
$$

Penalty $1=\max \quad(\vec{g}, 0)$

Penalty $2=\max \quad\left(\left(\alpha_{2}-\alpha_{1}\right), 0\right)$

where $D_{p r i}^{\prime}$ is the volume of water supplied for the priority demand each month $\left(\mathrm{m}^{3}\right), D_{p r i}$ is the monthly priority demand $\left(\mathrm{m}^{3}\right), \vec{g}$ is

Table 3. Summary of base scenarios.

\begin{tabular}{ccc}
\hline Scenarios & Variables & Period \\
\hline SOP1 & - & $1964-2012$ (588 months) \\
D1 & CR1, CR2, $\alpha_{1}, \alpha_{2}$ & \\
D2 & $\alpha_{1 \mathrm{R}}, \alpha_{1 \mathrm{~N}}, \alpha_{1 \mathrm{D}}, \alpha_{2 \mathrm{R}}, \alpha_{2 \mathrm{~N}}, \alpha_{2 \mathrm{D}}$ & $1964-2012$ (585 months) \\
\hline
\end{tabular}

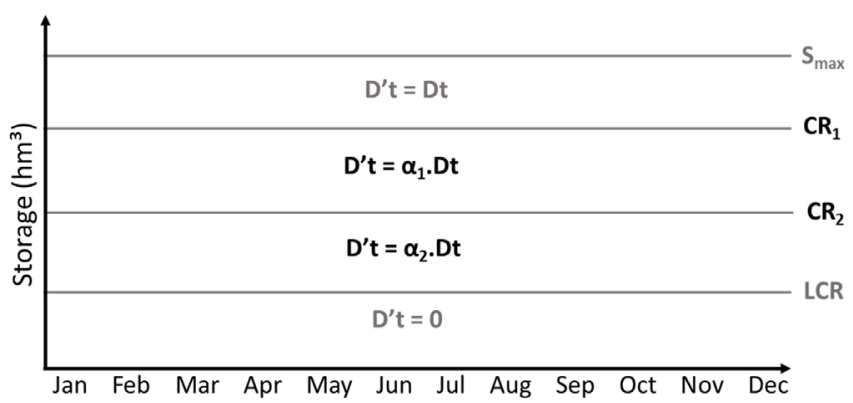

Figure 4. Schematic illustration of the operation rule curves with two-stage rationing (modified from Chiamsathit et al., 2014). 
the vector of the difference between $\mathrm{CR}_{2}$ and $\mathrm{CR}_{1}$ in each month, and $c$ is a weight applied to consider the different ranges between the alpha and CR values.

The purpose of scenario $\mathrm{D}_{2}$ was to find demand release coefficients that would also suit future inflows, in addition to the storage level (S). It was decided that flow data be worked with instead of precipitation data for the characterization of future water entry in the reservoir because in previous simulations of sensitivity analysis of the water balance models of semi-arid reservoirs, it was observed that the data on the meeting of the demands are much more sensitive to flow data than precipitation data, what was to be expected since the inflow is the result of the flow contribution in the entire hydrographic basin and the precipitation contributes only in the reservoir surface area. As there are inconsistencies in the flow and precipitation data (Figure 2), however, in determining the precipitation classification of the quarter for some periods, we tried to determine the release coefficients based on the data that were more representative of the quarter's water contribution: the flow rate data.

In this two-stage rationing process, $\alpha_{1}$ and $\alpha_{2}$ were subcategorized for the conditions in which the following quarter was rainy $(\mathrm{R})$, normal $(\mathrm{N})$, or dry (D), giving rise to six parameters: $\alpha_{1 \mathrm{R}}, \alpha_{1 \mathrm{~N}}, \alpha_{1 \mathrm{D}}, \alpha_{2 \mathrm{R}}, \alpha_{2 \mathrm{~N}}$, and $\alpha_{2 \mathrm{D}}$. It is important to clarify that the classification "rainy, normal and dry" will be used from now on, instead the INMET classification: "above normal, normal, below normal".

As $\mathrm{CR}_{1}$ and $\mathrm{CR}_{2}$ were obtained in $\mathrm{D}_{1}$ and the dead volume of the reservoir was defined as LRC, the optimization of the variables was subject only to the R1 constraint, which determines the water release hierarchy of $\alpha$ coefficients:

R1: $0 \leq \alpha_{2 \mathrm{D}} \leq \alpha_{2 \mathrm{~N}} \leq \alpha_{2 \mathrm{R}} \leq \alpha_{1 \mathrm{D}} \leq \alpha_{1 \mathrm{~N}} \leq \alpha_{1 \mathrm{R}} \leq 1$

To perform this simulation-optimization, it was necessary to compare the affluent flows accumulated in each quarter with the tertiles, and then to classify the quarters as dry, normal, or rainy if their classification is lower tertile, medium tertile, or upper tertile, respectively. For the steps of the monthly simulation of the reservoir's water balance, the first is verifying the volume of water accumulated in the reservoir (S), the second is verifying the affluent flow rate in the following quarter, and the third is determining whether the water demand was met in month (D ), assigning the demand release coefficient $(\alpha)$ corresponding to the stored volume and the classification of the precipitation for the following semester. The objective function of scenario $\mathrm{D}_{2}$ sought to maximize the efficiency of meeting the priority demand $\left(Y_{\text {pri }}\right)$ respecting the following penalties that ensures the conditions of R1:

$\operatorname{Ypri}(D 2)=\frac{\sum_{t=1}^{T} D_{p r i}^{\prime}}{\sum_{t=1}^{T} D_{p r i}}-$ c. (Penalty1 + Penalty2 + Penalty $3+$ Penalty4 + Penalty5) $(10)$
Penalty $1=\max \quad\left(\left(\alpha_{2 S}-\alpha_{2 N}\right), 0\right)$

Penalty $2=\max \quad\left(\left(\alpha_{2 N}-\alpha_{2 C}\right), 0\right)$

Penalty $3=\max \quad\left(\left(\alpha_{2 C}-\alpha_{1 S}\right), 0\right)$

Penalty $4=\max \quad\left(\left(\alpha_{1 S}-\alpha_{1 N}\right), 0\right)$

Penalty $5=\max \quad\left(\left(\alpha_{1 N}-\alpha_{1 C}\right), 0\right)$

After determining the values of the rationing levels and the water release coefficients, they were applied in different scenarios, as shown in Table 4.

Both the $\mathrm{SOP}_{1}$ and $\mathrm{SOP}_{2}$ scenarios used SOP. These scenarios are differentiated by the simulation period.

The current operating rule $(\mathrm{C})$ simulates the operation carried out in the Cruzeta reservoir, with rationing done in two stages (Figure 4) and with the rationing bands constant in all the months of the year, in which at least the priority demand is met when there is a volume above the operational minimum. In this scenario, $\mathrm{CR}_{1}=18.6 \mathrm{hm}^{3} ; \mathrm{CR}_{2}=17.7 \mathrm{hm}^{3} ; \alpha_{1}=0.37$; and $\alpha_{2}=0.058$.

In scenario $\mathrm{R}$, the rationing operation rule was simulated using the values of the parameters obtained in scenario $\mathrm{D}_{1}: \mathrm{CR}_{1}$, $\mathrm{CR}_{2}, \alpha_{1}$, and $\alpha_{2}$.

In the RF scenario, the reservoir operation rule was applied with rationing according to the stored volume and precipitation forecast. The values of the variables found in the base scenarios were applied here, according to INMET's seasonal forecast. For this, it was necessary to classify the forecast for the following quarter (from the climatic forecasts issued by INMET) for all the simulation months. The forecast for the following quarter was considered the average tertile when the same probability was indicated for the three categories.

In the RPF scenario, the reservoir operation rule with rationing according to the stored volume and the perfect forecast was applied. As mentioned earlier, the term perfect forecast refers to the condition in which the forecast can perfectly match the classification of the quarterly accumulated precipitation, verifying the maximum efficiency of the operation not affected by uncertainties. For this, it was necessary to classify (for all the

Table 4. Summary of application scenarios.

\begin{tabular}{ccc}
\hline Scenarios & Operation rule applied & Period \\
\hline $\mathrm{SOP}_{2}$ & Standard operating rule \\
$\mathrm{C}$ & Current operating rule for the reservoir & $2004-2012$ \\
$\mathrm{R}$ & Rationing rule with the variables derived from $\mathrm{D}_{1}$ & $(100$ months $)$ \\
$\mathrm{RF}$ & Rationing rule with precipitation forecast, rationing levels $\left(\mathrm{CR}_{1}\right.$ and $\left.\mathrm{CR}_{2}\right)$ of $\mathrm{D}_{1}$, and the coefficients of $\mathrm{D}_{2}$ & \\
$\mathrm{RPF}$ & Rationing rule with perfect precipitation forecast, rationing levels $\left(\mathrm{CR}_{1}\right.$ and $\left.\mathrm{CR}_{2}\right)$ of $\mathrm{D}_{1}$, and the coefficients of $\mathrm{D}_{2}$ & \\
\hline
\end{tabular}




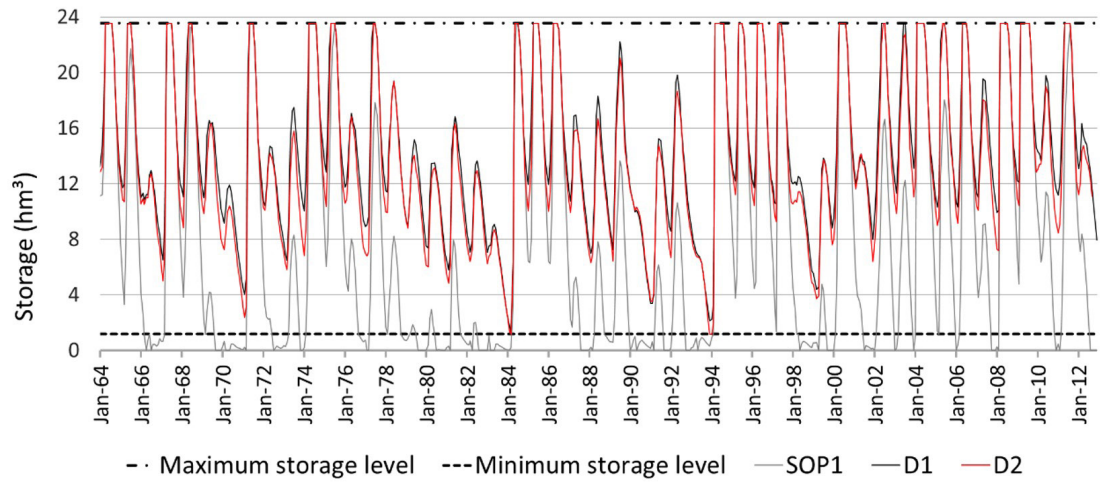

Figure 5. Volumetric evolution of the base scenarios.

Table 5. Limits of the quarterly normal-range affluent flow $\left(\mathrm{m}^{3} / \mathrm{s}\right)$.

\begin{tabular}{lcccccccccccc}
\hline \multirow{2}{*}{ QUARTER } & JAN & FEB & MAR & APR & MAY & JUN & JUL & AUG & SEP & OCT & NOV & DEC \\
& MAR & APR & APR & MAY & JUN & JUL & AUG & SEP & OCT & NOV & DEC & JAN \\
& MAN & JUL & AUG & SEP & OCT & NOV & DEC & JAN & FEB \\
\hline Lower limit & 0.45 & 1.72 & 3.13 & 3.60 & 2.78 & 1.48 & 0.60 & 0.15 & 0.00 & 0.00 & 0.00 & 0.04 \\
Upper limit & 1.40 & 3.86 & 6.22 & 6.99 & 5.49 & 3.33 & 1.57 & 0.56 & 0.12 & 0.00 & 0.04 & 0.28 \\
\hline
\end{tabular}

simulation months) the precipitation of the following quarters according to the reference of the INMET tertiles (Table 2), and to find the perfect forecast.

\section{RESULTS AND DISCUSSION}

\section{Base scenarios}

Scenario $\mathrm{D}_{1}$ optimized solution reached the following parameter values: $\mathrm{CR}_{1}=18.64 \mathrm{hm}^{3} ; \mathrm{CR}_{2}=14.86 \mathrm{hm}^{3} ; \alpha_{1}=0.375$; and $\alpha_{2}=0.159$.

To obtain the results of scenario $\mathrm{D}_{2}$, an ordered data sequence from 100-year affluent flow serie of the Cruzeta reservoir was performed for each quarter. The 1 st and 3 rd quartiles were obtained to delimit the lower and upper limits of the normal-range flow rate, as shown in Table 5.

From this reference for classifying the quarterly values analyzed in $\mathrm{D}_{2}$ as rainy, normal, or dry, it was possible to determine the optimal values of the pre-determined demand coefficients in the simulation-optimization. Thus, the optimal solution for $\mathrm{D}_{2}$ was the following parameter values: $\alpha_{1 \mathrm{R}}=0.886 ; \alpha_{1 \mathrm{~N}}=0.623$; $\alpha_{1 \mathrm{D}}=0.490 ; \alpha_{2 \mathrm{R}}=0.314 ; \alpha_{2 \mathrm{~N}}=0.165$; and $\alpha_{2 \mathrm{D}}=0.123$.

It was observed that for the same rationing range, the $\alpha_{1}$ coefficient of $D_{1}$ had a lower value than the coefficients optimized in $\mathrm{D}_{2}$. The $\alpha_{2}$ coefficient of $\mathrm{D}_{1}$ was less than two of three coefficients obtained in $\mathrm{D}_{2}$. Therefore, for equal storage ranges limited in $\mathrm{CR}_{1}$ and $\mathrm{CR}_{2}, \mathrm{D}_{2}$ provides more water than $\mathrm{D}_{1}$ to meet the demands, except for $\alpha_{2 \mathrm{D}}$ coefficient. Even so, it is relevant to note that the lowest coefficients obtained in $\mathrm{D}_{1}$ and $\mathrm{D}_{2}\left(\alpha_{2}\right.$ and $\left.\alpha_{2 \mathrm{D}}\right)$ provide more water than the priority demand, which corresponds to $5.8 \%$ of the total demand.

In Table 6, performance indicators of $\mathrm{D}_{1}$ and $\mathrm{D}_{2}$ are compared to those of $\mathrm{SOP}_{1}$. Regarding meeting the total demand, it was observed that $\mathrm{SOP}_{1}$ met more than $\mathrm{D}_{1}$ and $\mathrm{D}_{2}$ did. In contrast, $\mathrm{SOP}_{1}$ did not fully meet the priority demand in the simulation
Table 6. Performance indicators for the base scenarios.

\begin{tabular}{cccc}
\hline \multirow{2}{*}{$\begin{array}{c}\text { Performance } \\
\text { indicators }\end{array}$} & \multicolumn{3}{c}{ Base scenarios } \\
\cline { 2 - 4 } & $\mathbf{S O P}_{1}$ & $\mathbf{D}_{1}$ & $\mathbf{D}_{2}$ \\
\hline $\mathrm{Y}_{\text {total }}$ & 0.67 & 0.49 & 0.53 \\
$\mathrm{Y}_{\text {pri }}$ & 0.68 & 1.00 & 1.00 \\
\hline
\end{tabular}

period, while $\mathrm{D}_{1}$ and $\mathrm{D}_{2}$ were optimized to minimize these deficits. It was also observed that in $\mathrm{Y}_{\text {total }}, \mathrm{D}_{2}$ met the demands more than $\mathrm{D}_{1}$ did because its coefficients of water release were higher $\mathrm{D}_{1}$ 's coefficients.

Figure 5 shows water level behavior in the reservoir over the simulated period in the $\mathrm{SOP}_{1}, \mathrm{D}_{1}$ and $\mathrm{D}_{2}$ scenarios. It was observed that in $\mathrm{SOP}_{1}$, the reservoir storage was below dead volume in 23 periods over the simulated 49 years, its longest crisis interval, having been below dead volume for 21 consecutive months (July 1982-March 1984). In $\mathrm{D}_{1}$, reservoir storage did not reach dead volume, while $\mathrm{D}_{2}$ reached it in two periods (March 1984 and December 1993-January 1994). The optimized scenarios refused to reach the dead volume because they were optimized to attend at least the priority demands.

\section{Application scenarios}

Next, five application scenarios' detailed results regarding the release of water to meet the demands and the volumetric behavior of the reservoir will be presented.

Meeting the demands

It can be seen in Table 7 that, as in the base scenarios, $\mathrm{SOP}_{2}$ released the largest volume of water to meet the total demand but did not fully meet the priority demand. The other scenarios, on the other hand, fully met the priority demand and showed gains 
Table 7. Performance indicators for the application scenarios.

\begin{tabular}{cccccc}
\hline Performance & \multicolumn{3}{c}{ Application scenarios } \\
\cline { 2 - 6 } indicators & $\mathbf{S O P}_{2}$ & $\mathbf{C}$ & $\mathbf{R}$ & $\mathbf{R F}$ & 0.61 \\
\hline $\mathrm{Y}_{\text {total }}$ & 0.83 & 0.52 & 0.59 & 1.00 & 0.62 \\
$\mathrm{Y}_{\text {pri }}$ & 0.84 & 1.00 & 1.00 & 0.321 & 1.00 \\
$\mathrm{Y}_{\text {failure }}$ & 0.123 & 0.079 & 0.256 & 0.12 & 0.323 \\
$\mathrm{r}$ & 0.21 & 0.15 & 0.14 & 0.12 \\
\hline
\end{tabular}

Table 8. Meeting the demands (\%) in the application scenarios.

\begin{tabular}{cccccc}
\hline \multirow{2}{*}{ Demand service } & \multicolumn{3}{c}{ Application scenarios } & RF & RPF \\
\cline { 2 - 6 } & SOP $_{2}$ & C & 44 & 43 & 43 \\
Integral & 81 & 48 & 56 & 57 & 57 \\
Partial & 3 & 52 & - & - & - \\
No service & 16 & - & & R \\
\hline
\end{tabular}

in $\mathrm{Y}_{\text {total }}$ with the proposed operation rules. C scenario (current rationing rule for the reservoir) had the lowest attendance to the total demand $(52 \%)$, and $\mathrm{R}$ (rationing rule without the use of the precipitation forecast) had 59\%. RF had 61\%, showing gains by incorporating precipitation forecasts into decision making. RPF scenario showed the best performance (meeting $62 \%$ of the total demand) as it incorporated precipitation forecasts with no associated errors. It can be seen that from C to RPF, there was a $10 \%$ gain in total calls and RF's total calls are only $1 \%$ below RPF's.

As for the service in periods of failure (periods in which it was not possible to meet $100 \%$ of the total demand), $\mathrm{Y}_{\text {failure }}$ shows that $\mathrm{C}$ had the lowest water release, followed by $\mathrm{SOP}_{2}, \mathrm{R}, \mathrm{RF}$, and RPF. Scenario C, despite always meeting the priority demand, performed very conservative rationing with its coefficients, to the point that $\mathrm{SOP}_{2}$, in total, served more than $\mathrm{C}$ in the periods of failure. It can also be observed that rationing proposals optimized by GA improved this efficiency, especially RF, which came very close to RPF (the idealized situation) meeting more than $32 \%$ of the total demand.

Regarding scenarios resilience, a decrease was shown from $\mathrm{SOP}_{2}$ to RPF because this indicator considers any non-integral service a failure. $\mathrm{SOP}_{2}$ was the most resilient because it offered water to meet the demands without making reservations for the future. Therefore, although the system goes into crisis several times, when it recovers it meets the full value of the demand as soon as possible, showing more episodes of recovery than the other scenarios.

Table 8 shows percentage of time that meting demand is classified as integral, partial, and no service, in different scenarios. $\mathrm{SOP}_{2}$ fully met the demands more $(81 \%)$ than other scenarios did, but it did not respond in 16 months. $\mathrm{SOP}_{2}$ had five periods of failure, reaching five consecutive months with $D^{\prime}=0$ from October 2007 to February 2008. In three months that there was partial service, D' ranged from $60 \%$ to $99 \%$ of the total demand.

Unlike $\mathrm{SOP}_{2}$, other scenarios did not present a situation where $D^{\prime}=0 . C$ scenario met the demands completely more often than did optimized scenarios, because its storage range limits were different. The first range limit $\left(18.6 \mathrm{hm}^{3}\right)$ was very close to $\mathrm{CR}_{1}\left(18.64 \mathrm{hm}^{3}\right)$ but the limit of the second band was higher $\left(17.7 \mathrm{hm}^{3}\right)$ than $\mathrm{CR}_{2}$ one $\left(14.86 \mathrm{hm}^{3}\right)$. Thus, in $\mathrm{C}$, the reservoir entered the second rationing range earlier and preserved more water as it met the priority demand only when the water level was below $17.7 \mathrm{hm}^{3}$. Thus, it recovered its full-service limit level more quickly. In the same scenario, there was a failure period consisting of nine-time failures, and the longest consecutive period of partial service (June 2004 - March 2005), totaled 10 months in which only the priority demand was met.

$\mathrm{R}$ scenario attended full demand $4 \%$ less than $\mathrm{C}$ scenario did and 1\% more than RF and RPF. This happened because the CRs of optimized scenarios were constant, but most of RF and $\mathrm{RPF} \alpha$ coefficients, resulting from $\mathrm{D}_{2}$, were higher than those of $\mathrm{R}$. As $\mathrm{R}$ released less water than RF and RPF did (Table 8) during the simulation, its storage managed to reach the $\mathrm{CR}_{1}$ level in one more month. About partial service, $\mathrm{R}$ went through nine periods of failure, with $\alpha$ 's ranging from 0.16 to 0.38 for 10 consecutive months. As for RF and RPF, they went through eight periods of failure each, coming to remain in failure for 11 consecutive months, from November 2011 to September 2012, with RP's service ranging from 0.12 to 0.62 and RPF's ranging from 0.12 to 0.49 .

Still on meeting demands, Figure 6 shows the scenarios' average monthly attendance to demands. Scenario $C$ presents the lowest monthly averages in 10 of 12 months, but in April it presented an average of $100 \%$. SOP ${ }_{2}$ presented the highest monthly service averages, fully meeting the demands from April to July. These facts are attributed to scenario $\mathrm{C}$ conservative character, which met only the priority demand in its second rationing range, and to $\mathrm{SOP}_{2}$ consumer character, which supplied water until the reservoir reached the minimum volume. In seven of 12 months, $\mathrm{R}$ scenario met demand less than RF or RPF did due to its smaller $\alpha$ coefficient values.

It was observed that all operations carried out in different scenarios had a tendency to increase and decrease their attendance to the demands. The highest attendance averages were observed from April to September.

\section{Volume variations}

Figure 7 shows the water level behavior in the reservoir (S) over the simulated period in different application scenarios. 


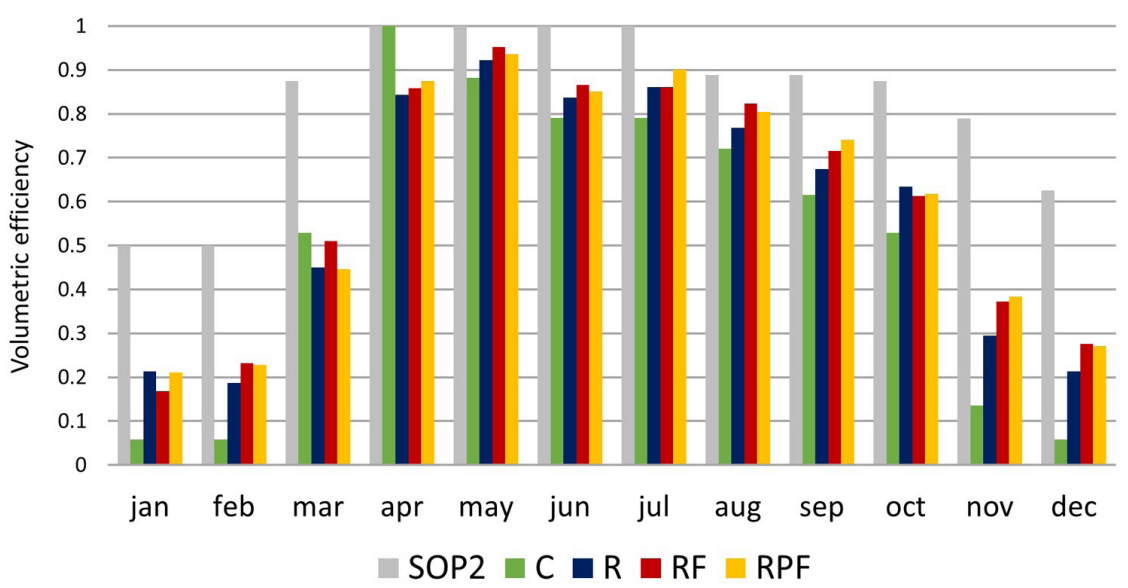

Figure 6. Monthly volumetric efficiency of the application scenarios.

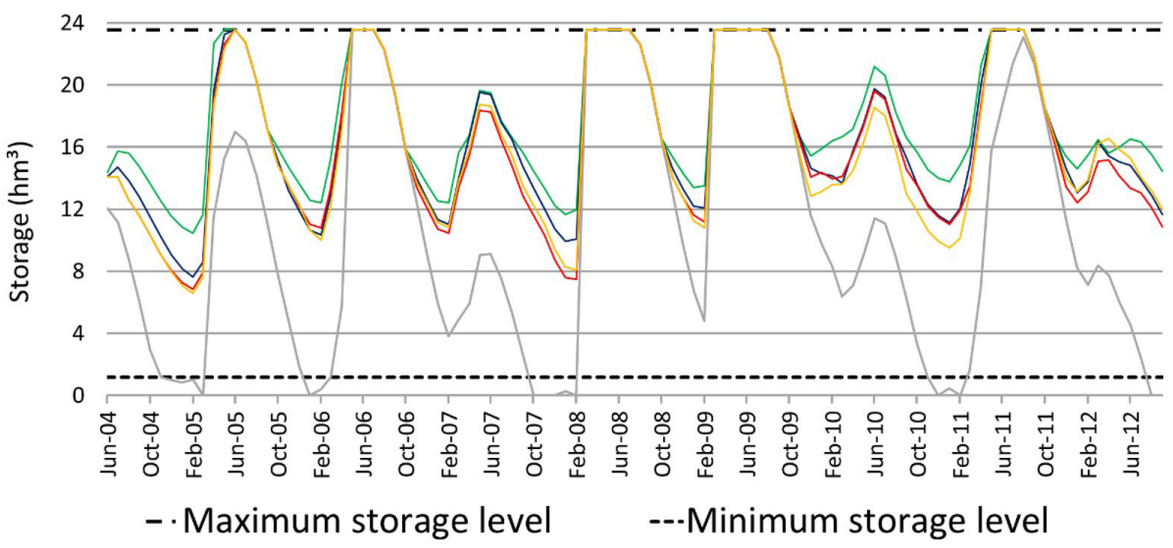

Figure 7. Volumetric evolution of the application scenarios.

It was observed that in $\mathrm{SOP}_{2}$, the reservoir was below dead volume in five periods over the simulated 100 months, its longest crisis interval with five consecutive months below dead volume (from October 2007 to February 2008), the same period as the greatest service deficit. This did not happen in other scenarios. Scenario C presented the highest storage levels because it was the scenario that least met the demands, as shown in Table 7 and 8 and Figure 6.

The reservoir overflowed in five periods, except $\mathrm{SOP}_{2}$, with one less period. The reservoir spilled less in $\mathrm{SOP}_{2}$ (14 months) and spilled more in scenario C (21 months). Optimized scenarios showed reduced overflow periods compared to scenario C, with 18 months for R, 19 for RF, and 18 for RPF. From March to August 2009, all scenarios showed the largest consecutive period of overflow, but there were different overflow volumes in the scenarios.

Figure 8 shows water volumes ratios lost by spillage $\left(V_{\text {spil }}\right)$ and by evaporation $\left(\mathrm{V}_{\text {evap }}\right)$ in relation to inflow volumes $\left(\mathrm{V}_{\text {inf }}\right)$ for each scenario. Despite high average annual evaporation of Cruzeta reservoir compared to average precipitation in the same period (Figure 2), it was observed that a greater volume was lost by spillage than by evaporation. This is due to the fact that main water inlet of the reservoir comes from affluent flow drained in the entire hydraulic basin, and evaporation affects only the liquid surface of reservoir.

It was observed that $\mathrm{SOP}_{2}$ lost less volume by spillage and by evaporation than the other scenarios: 64.4 and $9.00 \%$, respectively, of all water that flowed into the reservoir in simulated

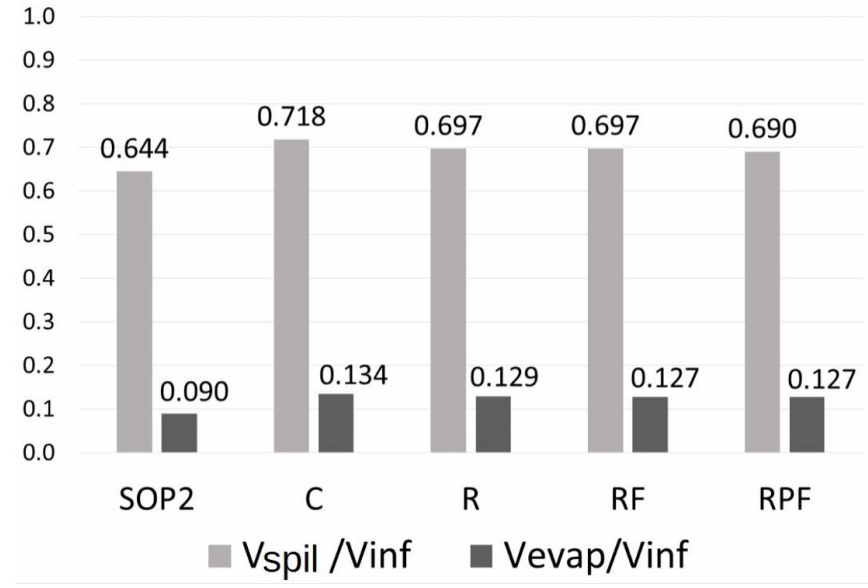

Figure 8. Ratios of lost water volume in the application scenarios.

period. This is because storage levels in $\mathrm{SOP}_{2}$ remained lower than those in other scenarios in all simulations, resulting in less spilled volume and smaller average areas for evaporation. The opposite happened in scenario $\mathrm{C}$, which had the biggest reasons for the occurrence of spillage and evaporation. Scenarios optimized in GA obtained very close or equal ratios, higher than $\mathrm{SOP}_{2}$ 's but lower than scenario C's.

Figure 9 shows the average monthly storage volume (\%) in scenarios. $\mathrm{SOP}_{2}$ had the lowest average, $\mathrm{C}$ had the highest, and 


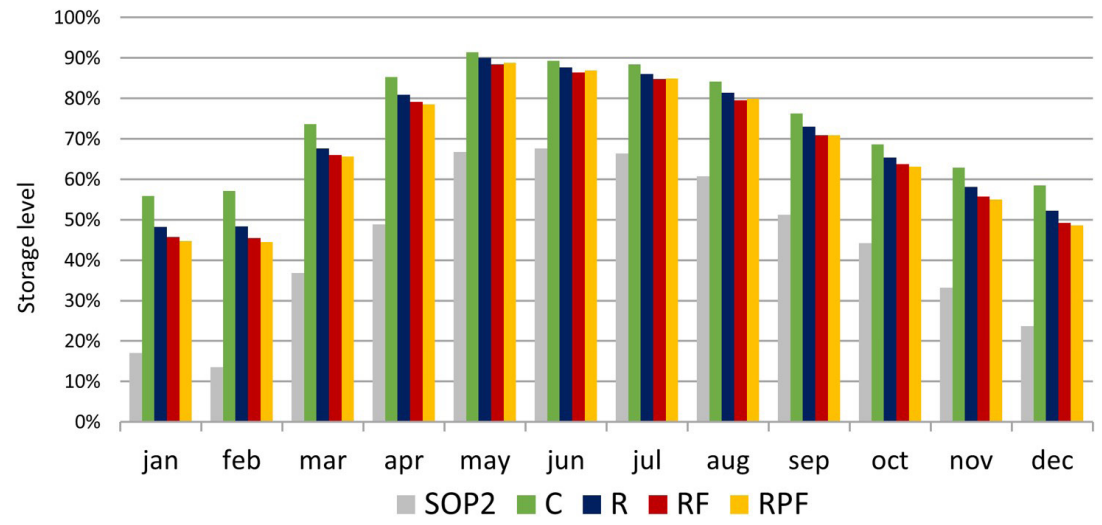

Figure 9. Average monthly storage levels of the application scenarios.

R's was always greater than RF's and RPF's, according what was shown in Figure 6. $\mathrm{SOP}_{2}$ had its highest average in June while other scenarios had theirs in May.

As shown in Figure 6, there was an increase and decrease trend over the months in all scenarios, and the semester AprilSeptember stood out with the highest averages. Thus, it is interesting to note that even in different simulated operations, average storage volume of the Cruzeta reservoir clearly shows seasonality. It can be seen in Figure 2 that January-June semester is the rainiest in Cruzeta reservoir, the February-July semester has the largest water inflows, and the April-August semester has the lowest evaporation rates. Therefore, this configuration of larger inlets and smaller outlets of water is decisive in reservoir's water balance.

Obviously, if there is more water stored in the AprilSeptember semester, it means that in this period a higher percentage of the demands can be met. The opposite happens in the October-March semester. The simulated operations with constant rationing bands throughout the year did not follow the predominant seasonal trend. Therefore, $\mathrm{CR}_{1}$ and $\mathrm{CR}_{2}$ can be optimized every semester so that more water can be supplied in the October-March semester without the reservoir going into crisis but releasing more water to meet the demands. In this way, the volume lost by spillage can also be reduced because in the semester when water is most abundant, more water will be needed to recover the low storage of the scarce semester.

\section{Comparison between scenarios}

Rationing scenarios in this study had advantages over SOP scenarios, which do not reserve water for future service. SOP scenarios met the priority demand minimally, with periods of deprivation for some demands to prevent no service. $\mathrm{SOP}_{2}$ 's consumer profile provided higher global levels of meeting the demands but kept the reservoir at its lowest levels compared to the other rules, including causing the system to collapse more often. Rationing policy is used for the Cruzeta reservoir as a remediation in times of crisis, but this strategy must be used preventively.

This study verified that rationing policy proposed by $\mathrm{C}$ scenario for Cruzeta reservoir guarantees meeting of the priority demands but is conservative in its percentages and rationing ranges. Service efficiency in the failure periods $\left(\mathrm{Y}_{\text {failure }}\right)$ of scenario
C (0.079) was lower than that $\mathrm{SOP}_{2}$ 's (0.123), which did not perform rationing. The same two-stage rationing configuration in $\mathrm{R}$ scenario showed that there might be more water release to meet the demands without lowering the reservoir's minimum operation level.

As for the incorporation of precipitation forecasts into the rationing policy, it was realized that the use of optimized coefficients subdivided into classes could improve the service even in periods of failure, making better use of storage volume. The perceived lag between precipitation and affluent flow does not become a problem, but an increase in the "alert time" for rainy and dry periods of inflow does. Precipitation forecast is quarterly, and precipitation period is prior to the affluent flow. Then, rationing is triggered by the forecast indication, which indirectly communicates the future inflow. If forecast is below normal rainfall for the next quarter, it indicates that little inflow will come in the following months, and rationing will preserve water for the scarcity period. When the opposite happens, more water is used because volumes are expected to recover in the future.

Inflow is the most relevant water input for reservoirs because it drains water from the entire hydraulic basin while the precipitation input affects only the water mirror. For this reason, coefficients were optimized in this study to suit this variable. However, there is no forecast of inflow, only precipitation, and if precipitation indirectly announces the inflow to the reservoir, it can be useful for preventing crises in reservoirs in semi-arid areas.

INMET's (Instituto Nacional de Meteorologia, 2019b) forecasts were compared to rainfall of the same period presented by the historical series. Of the 100 quarters compared, the quarter classifications coincided 44 times ( 9 dry, 25 normal and 10 rainy quarters). Table 9 shows the details of these incompatibilities.

Half of these classification underestimated rainfall, the other half overestimated it, and most of these errors were concentrated in the normal classification. So the small difference between RF and RPF performance indicators is not due to the fact that we had a good forecast accuracy, but probably because errors of overestimation and underestimation were compensated. However, it is possible to notice by monthly volumetric efficiency (Figure 9), that there is a seasonal difference between RF and RPF due to the low accuracy between the INMET's forecast and the rainfall occurred at the quarters simulated. 
Table 9. Forecast Accuracy.

\begin{tabular}{|c|c|c|c|}
\hline \multicolumn{2}{|c|}{ INMET's Forecast } & \multicolumn{2}{|c|}{ Rainfall occurred } \\
\hline Number of quarters & Humidity of the quarter & Number of quarters & Humidity of the quarter \\
\hline \multirow[t]{2}{*}{9} & Dry & 6 & Normal \\
\hline & & 3 & Rainy \\
\hline \multirow[t]{2}{*}{46} & Normal & 27 & Dry \\
\hline & & 19 & Rainy \\
\hline 1 & Rainy & 1 & Normal \\
\hline
\end{tabular}

\section{CONCLUSIONS}

SOP should not be applied to reservoirs located in regions suffering from water scarcity, such as semi-arid regions, because once the reservoir is depleted, its storage levels cannot be easily recovered. Therefore, operation rules must be developed and put in place to mitigate crises. The rationing scenarios optimized by GA in this study showed intermediate results between the high consumption of the SOP rule and the conservatism of the rule currently applied to the reservoir $(\mathrm{C})$. The study results were made the bases of proposals for reservoir operations that make the most of water availability without causing the reservoir to collapse.

The increase in periods of failure (less than 100\% service) through operation with rationing is beneficial to meeting the demands of reservoirs built in semi-arid regions because the water savings realized in some periods can prevent water crises, allowing the priority demand to be fully met and improving service in periods of failure and low water availability.

Adding precipitation forecasts to the rationing policy optimized by GA brought gains in the reservoir's efficiency because they increased the volumetric reliability and service efficiency in the periods of failure. Despite the inaccuracies in the forecasts, this scenario (RF) came very close to the ideal condition, the rationing scenario with perfect forecasts (RPF).

The adoption of a rationing rule makes reservoirs perform their function of providing water over time more efficiently as such rule regulates water availability, utilizes the accumulated water wisely, and manages the discharge of water to meet the demands. The use of climate forecasts makes it possible to use information about the future precipitation scenario and thus optimize reservoirs' services in the most critical conditions (with less water availability). However, in all the simulated scenarios in this study, despite the different operations implemented, the seasonal behavior of the Cruzeta reservoir persisted in terms of storage level and demands.

\section{ACKNOWLEDGEMENTS}

This study was financed in part by the Coordenação de Aperfeiçoamento de Pessoal de Nível Superior - Brasil (CAPES) Finance Code 001, and by the Conselho Nacional de Pesquisa CNPq (proc. 438271/2018-1). The authors are grateful for the support.

\section{REFERENCES}

Adeloye, A. J., \& Dau, Q. V. (2019). Hedging as an adaptive measure for climate change induced water shortage at the Pong reservoir in the Indus Basin Beas River, India. The Science of the Total Environment, 687, 554-566. PMid:31220712. http://dx.doi. org/10.1016/j.scitotenv.2019.06.021.

Agência Nacional de Águas - ANA, \& Ministério do Meio Ambiente. (2016a). Plano de Recursos Hídricos da Bacia Hidrográfica do Rio PiancóPiranbas-Açu - Resumo Executivo (160 p.). Brasília: ANA. Retrieved in 2021, January 15, from http://piranhasacu.ana.gov.br/produtos/ PRH_PiancoPiranhasAcu_ResumoExecutivo_30062016.pdf

Agência Nacional de Águas - ANA, \& Ministério do Meio Ambiente. (2016b). Plano de Recursos Hídricos da bacia hidrográfica do Rio PiancóPiranbas-Açu (relatório técnico) (195 p.). Brasília: ANA. Retrieved in 2021, January 15, from http://piranhasacu.ana.gov.br/produtos/ PRH_PiancoPiranhasAcu_RelatorioTecnicoAnexosDigitais.pdf

Agência Nacional de Águas - ANA. (2017). Reservatórios Do Semiárido Brasileiro: Hidrologia, Balanço Hídrico e Operação - Relatório Síntese $(88$ p.). Brasília: ANA. Retrieved in 2021, January 15, from https:// www.ana.gov.br/noticias/estudo-reservatorios/reservatorios-dosemiarido-brasileiro_hidrologia-balanco-hidrico-e-operacao-1.pdf

Agência Nacional de Águas - ANA. (2020). Açudes do Semiárido (Saiba Mais). Brasília: ANA. Retrieved in 2021, January 15, from https://www.ana.gov.br/sala-de-situacao/acudes-do-semiarido/ acudes-do-semiarido-saiba-mais

Allawi, M. F., Jaafar, O., Mohamad Hamzah, F., Koting, S. B., Mohd, N. S. B., \& El-Shafie, A. (2019). Forecasting hydrological parameters for reservoir system utilizing artificial intelligent models and exploring their influence on operation performance. Knowledge-Based Systems, 163, 907-926. http://dx.doi.org/10.1016/j. knosys.2018.10.013.

Anand, J., Gosain, A. K., \& Khosa, R. (2018). Optimisation of multipurpose reservoir operation by coupling soil and water assessment tool (SWAT) and genetic algorithm for optimal operating policy (case study: Ganga River Basin). Sustainability (Switzerland), 10(5), 1660. http://dx.doi.org/10.3390/su10051660.

Associação Brasileira das Empresas Estaduais de Saneamento AESBE. (2017). Cruzeta (RN) tem abastecimento retomado pela Caern. Brasília: AESBE. Retrieved in 2021, January 15, from https:// aesbe.org.br/cruzeta-rn-tem-abastecimento-retomado-pela-caern/

Block, P. J., Souza Filho, F. A., Sun, L., \& Kwon, H. H. (2009). A streamflow forecasting framework using multiple climate and hydrological models. Journal of the American Water Resources 
Association, 45(4), 828-843. http://dx.doi.org/10.1111/j.17521688.2009.00327.x.

Bolouri-Yazdeli, Y., Bozorg Haddad, O., Fallah-Mehdipour, E., \& Mariño, M. A. (2014). Evaluation of real-time operation rules in reservoir systems operation. Water Resources Management, 28(5), 715-729. http://dx.doi.org/10.1007/s11269-013-0510-1.

Bravo, J. M., Collischonn, W., Tucci, C. E. M., \& Pillar, J. V. (2008a). Otimização de regras de operação de reservatórios com incorporação da previsão de vazão. Revista Brasileira de Recursos Hídricos, 13(1), 181-196. http://dx.doi.org/10.21168/rbrh.v13n1. p181-196.

Bravo, J. M., Collischonn, W., Pilar, J. V., Silva, B. C., \& Tucci, C. (2008b). Avaliação dos benefícios de previsões de vazão na operação de reservatórios. Revista Brasileira de Recursos Hídricos, 13(1), 197-213.

Campos, J. N. B. (2015). Paradigms and Public Policies on Drought in Northeast Brazil: A Historical Perspective. Environmental Management, 55(5), 1052-1063. PMid:25604214. http://dx.doi. org/10.1007/s00267-015-0444-x.

Castro, M. H. F. M., Oliveira, C. J. S., \& Medeiros, J. D. F. (2018). Alocação de água em reservatórios de regiões semiáridas. In: Anais do XIV Simpósio de Recursos Hidrícos do Nordeste. Porto Alegre: Associação Brasileira de Recursos Hídricos.

Chang, L. C., Chang, F. J., Wang, K. W., \& Dai, S. Y. (2010). Constrained genetic algorithms for optimizing multi-use reservoir operation. Journal of Hydrology (Amsterdam), 390(1-2), 66-74. http:/ / dx.doi.org/10.1016/j.jhydrol.2010.06.031.

Chiamsathit, C., Adeloye, A. J., \& Soudharajan, B. (2014). Genetic algorithms optimization of hedging rules for operation of the multi-purpose Ubonratana Reservoir in Thailand. Proceedings of the International Association of Hydrological Sciences, 364, 507-512. https://doi.org/10.5194/piahs-364-507-2014.

Choubin, B., Khalighi-Sigaroodi, S., Malekian, A., Ahmad, S., \& Attarod, P. (2014). Drought forecasting in a semi-arid watershed using climate signals: a neuro-fuzzy modeling approach. Journal of Mountain Science, 11(6), 1593-1605. https://doi.org/10.1007/ s11629-014-3020-6.

Fan, F. M., Schwanenberg, D., Alvarado, R., Assis dos Reis, A., Collischonn, W., \& Naumman, S. (2016). Performance of Deterministic and Probabilistic Hydrological Forecasts for the Short-Term Optimization of a Tropical Hydropower Reservoir. Water Resources Management, 30(10), 3609-3625. http://dx.doi. org/10.1007/s11269-016-1377-8.

Ficchí, A., Raso, L., Dorchies, D., Pianosi, F., Malaterre, P. O., Van Overloop, P. J., \& Jay-Allemand, M. (2016). Optimal operation of the multireservoir system in the seine river basin using deterministic and ensemble forecasts. Journal of Water Resources Planning and
Management, 142(1), 05015005. http://dx.doi.org/10.1061/(ASCE) WR.1943-5452.0000571.

G1 RN. (2015). Seca faz subirpara 17 número de cidades em colapso no $R N$. Retrieved in 2021, January 15, from http://g1.globo.com/ $\mathrm{rn} /$ rio-grande-do-norte/noticia/2015/11/seca-faz-subir-para17-numero-de-cidades-em-colapso-no-rn.html

G1 RN. (2018). Cruzeta, RN, volta a ter água nas torneiras e número de cidades em colapso cai para 12. Retrieved in 2021, January 15, from https://g1.globo.com/rn/rio-grande-do-norte/noticia/ cruzeta-rn-volta-a-ter-agua-nas-torneiras-e-numero-de-cidadesem-colapso-cai-para-12.ghtml

Gondim, J., Fioreze, A. P., Flecha, R., \& Alves, F. (2017). A seca atual no Semiárido nordestino - Impactos sobre os recursos hídricos. Parcerias Estratégicas, 22(44), 277-300.

Grupo Agora RN - AGORARN. (2016). Cruz̧eta sai da situação de colapso no abastecimento de água. Natal: AGORARN. Retrieved in 2021, January 15, from https://agorarn.com.br/noticia/cruzetasai-da-situacao-de-colapso-no-abastecimento-de-agua/

Grupo Agora RN - AGORARN. (2019). Municípios de Cruzeta e João Dias deixam situação de colapso no abastecimento. Natal: AGORARN. Retrieved in 2021, January 15, from https://agorarn.com.br/ cidades/municipios-de-cruzeta-e-joao-dias-deixam-situacao-decolapso-no-abastecimento/

Guo, H., Bao, A., Liu, T., Jiapaer, G., Ndayisaba, F., Jiang, L., Kurban, A., \& De Maeyer, P. (2018). Spatial and temporal characteristics of droughts in Central Asia during 1966-2015. The Science of the Total Environment, 624, 1523-1538. PMid:29929262. http://dx.doi. org/10.1016/j.scitotenv.2017.12.120.

Índia. Government of India. (2016). Drought Management Manual. Índia: Ministry of Agriculture and Farmers Welfare. Retrieved in 2021, January 15, from http://agricoop.nic.in/sites/default/files/ Manual Drought 2016.pdf

Instituto Nacional de Meteorologia - INMET. (2019a). Faixa Normal da Precipitação Trimestral. Retrieved in 2021, January 15, from http://www.inmet.gov.br/portal/index.php?r=clima/ faixaNormalPrecipitacao'Trimestral2

Instituto Nacional de Meteorologia - INMET. (2019b). Previsão Sazonal do INMET. Retrieved in 2021, January 15, from http:/ / www.inmet.gov.br/portal/index.php?r=clima/prev_estocastica

Instituto Nacional de Meteorologia - INMET. (2020). Boletins de Prognóstico Climático. Retrieved in 2021, January 15, from http:// www.inmet.gov.br/portal/index.php? $r=$ clima/prognostico ClimaticoTrimestral

Koch, H., Selge, F., de Azevedo, J. R. G., Souza da Silva, G. N., Siegmund-Schultze, M., \& Hattermann, F. F. (2018). Reservoir operation and environmental water demand: Scenarios for the Sub- 
Middle and Lower São Francisco River basin, Brazil. Ecohydrology, 11(8), 1-12. http://dx.doi.org/10.1002/eco.2026.

Lúcio, P. S., Silva, F. D. S., Fortes, L. T. G., Santos, L. A. R., Ferreira, D. B., Salvador, M. A., Balbino, H. T., Sarmanho, G. F., Santos, L. S. F. C., Lucas, E. W. M., Barbosa, T. F., \& Dias, P. L. S. (2010). Um modelo estocástico combinado de previsão sazonal para a precipitação no Brasil. Revista Brasileira de Meteorologia, 25(2), 70-87. http://dx.doi.org/10.1590/S0102-77862010000100007.

Marengo, J. A., Alves, L. M., Alvala, R. C. S., Cunha, A. P., Brito, S., \& Moraes, O. L. L. (2018). Climatic characteristics of the 2010-2016 drought in the semiarid northeast Brazil region. Anais da Academia Brasileira de Ciências, 90(2, Suppl.1), 1973-1985. PMid:28813107. http:/ /dx.doi.org/10.1590/0001-3765201720170206.

Michalewicz, Z. (1992). Genetic algorithms + data structures = evolution programs. Berlin: Springer-Verlag Berlin Heidelberg.

Mishra, A. K., \& Singh, V. P. (2010). A review of drought concepts. Journal of Hydrology (Amsterdam), 391(1-2), 202-216. http:/ /dx.doi. org/10.1016/j.jhydrol.2010.07.012.

Nohara, D., \& Hori, T. (2018). Reservoir operation for water supply considering operational ensemble hydrological predictions. Journal of Disaster Research, 13(4), 650-659. http://dx.doi.org/10.20965/ jdr.2018.p0650.

Nunes, T. H. C., Galvão, C. O., \& Rêgo, J. C. (2016) Rule curve for seasonal increasing of water concessions in reservoirs with low regularized discharges. Revista Brasileira de Recursos Hidricos, 21(3), 493-501. https://doi.org/10.1590/2318-0331.011615146.

Pallottino, S., Sechi, G. M., \& Zuddas, P. (2005). A DSS for water resources management under uncertainty by scenario analysis. Environmental Modelling \& Software, 20(8), 1031-1042. http://dx.doi. org/10.1016/j.envsoft.2004.09.012.

Peng, A., Zhang, X., Peng, Y., Xu, W., \& You, F. (2019). The application of ensemble precipitation forecasts to reservoir operation. Water Science and Technology: Water Supply, 19(2), 588-595. http:/ /dx.doi.org/10.2166/ws.2018.105.

R Core Team. (2018). R: a language and environment for statistical computing. Vienna, Áustria: R Foundation for Statistical Computing

Ragab, R., \& Prudhomme, C. (2002). SW: soil and Water. Climate change and water resources management in arid and semi-arid regions: prospective and challenges for the 21 st century. Biosystems Engineering, 81(1), 3-34. http://dx.doi.org/10.1006/bioe.2001.0013.

Rio Grande do Norte. Governo do Estado. Secretária de Meio Ambiente, Recursos Hídricos e Saneamento Básico - SEMARH. (2020). Ficha técnica do Reservatório Cruzeta. Natal: SEMARH.
Retrieved in 2021, January 15, from http:/ / sistemas.searh.rn.gov. br/MonitoramentoVolumetrico/Monitoramento/FichaTecnica? idReservatorio $=1070$

Rittima, A. (2009). Hedging policy for reservoir system operation: A case study of mun bon and lam chae reservoirs. Witthayasan Kasetsat Witthayasat, 43(4), 833-842.

Scrucca, L. (2013). GA : A Package for Genetic Algorithms in R. Journal of Statistical Software, 53(4), 1-37. http://dx.doi.org/10.18637/ jss.v053.i04.

Trambauer, P., Maskey, S., Winsemius, H., Werner, M., \& Uhlenbrook, S. (2013). A review of continental scale hydrological models and their suitability for drought forecasting in (sub-Saharan) Africa. Physics and Chemistry of the Earth, 66, 16-26. http://dx.doi. org/10.1016/j.pce.2013.07.003.

Tu, M.-Y., Hsu, N.-S., \& Yeh, W. W.-G. (2003). Optimization of reservoir management and operation with hedging rules. Journal of Water Resources Planning and Management, 129(2), 86-97. http:/ / dx.doi.org/10.1061/(ASCE)0733-9496(2003)129:2(86).

Wafae, E. H., Driss, O., Bouziane, A., \& Hasnaoui, M. D. (2016). Genetic Algorithm applied to reservoir operation optimization with emphasis on the Moroccan context. In Proceedings of the $3 \mathrm{rd}$ International Conference on Logistics Operations Management (GOL). USA: IEEE. https://doi.org/10.1109/gol.2016.7731678.

Yao, H., \& Georgakakos, A. (2001). Assessment of folsom lake response to historical and potential future climate scenarios 2 . Reservoir management. Journal of Hydrology (Amsterdam), 249(1-4), 176-196. http://dx.doi.org/10.1016/S0022-1694(01)00418-8.

\section{Authors contributions}

Andressa Adna Cavalcante Morais: Conceptualization, data curation, formal analysis, investigation, methodology, software, validation, visualization, writing - original draft, writing - review \& editing

Adelena Gonçalves Maia: Conceptualization, methodology, project administration, supervision, writing - original draft, writing - review \& editing.

Editor in-Chief: Adilson Pinheiro

Associated Editor: Fernando Mainardi Fan 